\title{
The Identity Construction of Da'wah Leadership on Jama'ah Tabligh Movement
}

\author{
Dudy Imanuddin Effendi ${ }^{*} \&$ Dudi Rustandi ${ }^{2}$ \\ ${ }^{1}$ UIN Sunan Gunung Djati Bandung \\ 2 Politeknik LP3I Bandung \\ *email :dudy.imanuddin@uinsgd.ac.id
}

\begin{abstract}
The process of leadership emergence drives the presence of religious, social groups. The purpose of this study is to find (1) the concept of leadership of the Tablighi Jamaah from various perspectives; Sufism, jurisprudence, laity, and religious authority; (2) Construction of the identity of the spiritual direction of the Jamaah Tabligh. The research paradigm uses virtual ethnographic methods with social identity construction theory. The results showed that (1) the concept of leadership in the Tablighi Jamaah emphasized more on religious authority and charismatic leadership (2) The construction of the religious identity of the leadership dimension of the Tablighi Jama'at was a combination of charismatic and transformational influence. This research can impact the leadership model of social and religious institutions in Indonesia as a model that is quite effective in creating observance of worshipers.
\end{abstract}

Keywords : Jamaah Tabligh; Leadership; Identity Construction.

\begin{abstract}
ABSTRAK
Kehadiran kelompok sosial keagamaan didorong oleh proses munculnya kepemimpinan. Tujuan penelitian ini adalah untuk menemukan (1) konsep kepemimpinan Jamaah Tabligh dari beragam perspektif; sufistik, yurisprudensi, awam, dan otoritas keagamaan; (2) Konstruksi identitas kepemimpinan agama Jamaah Tabligh. Paradigma penelitian menggunakan metode etnografi virtual dengan teori konstruksi identitas social. Hasil penelitian menunjukkan bahwa (1) konsep kepemimpinan pada Jamaah Tabligh lebih menekankan pada otoritas keagamaan dan kepemimpinan yang bersifat kharismatik (2) Konstruksi identitas keagamaan dimensi kepemimpinan Jama'ah Tabligh merupakan perpaduan antara otoritas kharisma dan transformasional. Penelitian ini dapat berdampak terhadap model kepemimpinan instusi social maupun keagamaan di Indonesia sebagai model yang cukup efektif dalam menciptakan ketaatan jamaah.
\end{abstract}

Kata kunci : Jamaah Tabligh; Kepemimpinan; Konstruksi Identitas. 


\section{INTRODUCTION}

The presence of social communities affiliated with religion always gives birth to a leader who becomes the reference and direction of movement. Even some sociologists in various analyzes have asserted that a community group can't be born without the presence of a leader. According to them, as long as there are parties who are influenced and directed. Historically, this leadership problem has the same age as human history.

The Tablighi Jama'ah, as an organized religious movement, has a leader and leadership. Tablighi Jama'ah, as a religious movement, agreed with Nottingham (Nottingham, 1996: 155), that every move organized to broadcast a new interpretation of an existing religion. For example, the major world religions, namely Buddhism, Christianity, and Islam, can be considered the result of religious movements. Likewise, religious movements are the result of developing or criticizing established religions such as the Francis and Protestant movements in Catholicism. In general, these religious movements go through a series of stages of their first development of the established changes. The phases of the religious movement in the next step will be a source of diversification in various matters relating to the development of the religious movement organization.

Competence in the religious field and personality of a founder is a magnet that has a binding force of attraction for others. This founding trait is usually called charismatic. Next, the second phase of the movement of the surrogate generation of surrogates appeared. Habitually the substitute naturally or forced always to play a role to solve, explain and parse essential problems concerning the organization, beliefs, rites, and normative rules that were left dormant during the founder's time. In this second stage, religious movements begin to find an organization by disciplining the various attributes of the tendency to have similarities in beliefs, rites, and ethical norms that remain grounded in the pure form they worship. The arrival of trusted future generations often accelerates the second phase, and the formulation of requirements for members starts to become more assertive. The distribution of organizational power refers to the belief of the saint and the mission of the founder. The formulation was subsequently positioned as the theology and official normative rules for the religious movement (Nottingham, 1996: 156).

Based on the explanation above, the leadership dimension can create specific religious identity constructions. The identity construction is caused by the leader as part of leadership indirectly having authority in determining the face and form of the religious organization he leads.

In connection with the discussion of the construction of religious identity, the leadership dimension of the Tablighi Jama'ah has experienced quite exciting debate. Based on the historical and ethnographic literature on Tablighi Jama'ah 
and politics, it can be seen that the discourse of leadership authority in the organization of this movement. The discussion shows differences of opinion regarding the organization of Tablighi Jama'ah. It is implicitly related to disagreement about the structure of authority in action (power). One side holds that the organizational characteristics of the Tablighi Jama'ah are very rigid. Showing governed by regulations and even totalitarian implies the structure of authority in the Tablighi Jama'ah, leaving little leeway for diversity in its membership. This description suggests an emphasis on top-down leadership in a system where elite leaders strongly determine and enforce the rules for behavior in all levels of the organization. On the other hand, however, this conception of organizational leadership contrasts directly with the "grassroots" character of the religious movements displayed by the Jama'ah Tabligh (Digby, 2006: 711).

Research on the construction of leadership identity was conducted by Hasyim (2018) about the governor of Jakarta's leadership, related to the development of Basuki Tjahaya Purnama's preaching. Using a semiotic approach, the results of his research concluded that the identity construction of Detik.com about Ahok emphasizes the negative side, highlighting the arrogant and unethical character. Kompas.com describes the development of Ahok's identity as a professional, credible, creative, and innovative leader in carrying out his duties as the Governor of DKI Jakarta with an emphasis on competence and credibility. But there is an inconsistency in reporting, researchers conducted by Detik.com rather than Kompas.com, wherein the decade leading up to the 2017 DKI Jakarta Governor Election, the construction of Ahok's leadership identity is favorable compared to 2018 .

Hasfi, Usman, and Santosa (2017) conducted a 2014 Presidential Candidate Representation in Leadership study. The research method uses a critical paradigm approach to Critical Discourse Analysis. The results showed that a fruitful political discussion on 'Twitter about presidential candidates' political leadership is not determined by rational discussion (egalitarian, consensus, regular communication, etc.) but by political actors. They are skilled at building the image of a presidential candidate's political leadership.

Other research was carried out by Mustain (2018) on the Role of the Islamic Power Center in the Construction of Islamic Identity in Lombok. He was using qualitative methods. The results showed, there was a role for the governor, namely Dr. TGH. Zainul Madjdi or Tuan Guru Bajang (TGB) in the Islamic Center construction in Mataram Lombok. That role was manifested in the TGB's strong commitment, initiating the building of an Islamic Center that had been rolling since the three previous governors' leadership could be realized. His duty was manifested in the form of APBD support throughout the first period of his administration. TGB also established the UPT Islamic Center as the unit responsible for managing the Islamic Center.

Mundiri and Bariroh (2018) conducted a study of the transformation of 
Kyai's leadership identity representation in superiors and subordinate relations. Through the descriptive qualitative research method, the results of the study show that the change of the description of the clerical leadership identity in the relationship between superiors and subordinates has begun to erode with the existence of global transformation. An ethical shift in the relationship between superiors and subordinates is shown by the form of leadership transformation seen through the way the Master instructs his subordinates by not using his right hand as a pointer. In the aspect of behavior, the Master arbitrarily ordered his subordinates with a high voice so that it seemed "mocked" in the form of orders.

The object of the Tablighi Jamaah research was carried out by Hasanah (2014) about the existence of the Tablighi Jamaat group and the reaction of the people of Jakarta. Through qualitative research methods with the theory of information diffusion approach, the results of the study show that the members of Tablighi Jamaah refer to the book Fadailul' Amal, which teaches innovation in Islamic propagation. The tradition of outdoor sermons (khuruj and khillah) and methods for inviting people to do good deeds (Jaulah). They have Amir as their leader and use the mosque as the center of their da'wah activities.

Another study on Tablighi Jamaah was conducted by Munir (2017) using a qualitative research paradigm of the meaning approach. The results showed that the lifestyle of the Tablighi Jamaah was based on understanding the concept of six companions. They believe that God has determined their fortune and the necessities of life. But humans are obliged to seek and strive. They assume that matter becomes an integral part of life, but it is not the purpose of life. The concept is the basis for interacting and acculturating with a new atmosphere. Finally, the process can be utilized and form a healthy competition climate and end with the prosperity and harmony of life.

Research on the leadership of the Tablighi Jamaah, conducted by Arifin (2017), which discusses the authority of the spiritual leadership of the Tablighi Jamaah at Temboro Islamic Boarding School. This study found three power of the Temboro Islamic Boarding School leadership through a phenomenological approach to religion, namely traditional, charismatic, and rational. First, conventional power comes from three traditions, namely: (1) pesantren education, (2) Tablighi Jamaat, and (3) Naqsyabandiyah-Khalidiyah order. Second, charismatic authority comes from the spiritual quality of the Master and is strengthened by karomah. Third, rational authority is based on the reasonable effort of the Master in opening formal madrassas as a form of modernization of Islamic educational institutions.

Based on previous research, it can be found that research on the construction of identity does not refer to the objectivity of the Tablighi Jamaah leadership, nor about the Tablighi Jamaah. Previous studies of the direction of 
the Tablighi Jamaat used a phenomenological approach. So that research on the construction of the missionary leadership identity of the Jamaah Tabligh has a novelty that is quite strong. In contrast to the most recent studies. At the same time, this research's impact is expected to be a scientific contribution in the field of missionary leadership, both practically and academically.

\section{RESULTS AND DISCUSSION}

\section{The Concept of 'Tablighi Jama'ah Leadership}

Based on the findings of the field, one of the leadership orientations in the Tablighi Jama'ah movement is to combine an esoteric mystical approach and strictly pay attention to the exoteric practice approach (Schoun, 1987: 79-80). Findings Investigation of the leadership structure in the Tablighi Jama'ah has revealed that the source of authority qualifications is based on mystical charism, jurisprudence, and manuscripts. Mystical charisma, jurisprudential competence, and documents have significantly contributed to the building of authority in the Tablighi Jama'ah movement. The power was supported by the help of a discursive tradition about manuscripts that they believed was true. This has become the specific identity of the leading construction of the Tablighi Jama'ah movement compared to other actions, which are sometimes based mostly on genetic charisma or normative rules of organization (jurisprudence). But the other side ignores footholds relating to the compilation of religious manuscripts, be it the Qur'an, the hadith, or the results of ijtihad on the ulama of Ahlul Sunah wal Jam'ah who had lived before.

The leadership context which originates from mystical charisma in the Tablighi Jama'ah movement, according to Simon Digby, is related to medieval Sufism literature, which has described mystical attributes in the Sufistic world as a source of authoritative legitimacy. The source of authority that comes from the Sufistic world namely; descendants of the Prophet or his companions; there is a relationship with Sufi circles; orthodoxy reputation; obedience in worship; mastering Islamic doctrine and Sufi sources; have literacy skills; has supernatural powers; have a reputation in facing life test; care for students and their people, and can feel the presence of God through dhikr. A leader or sheik must have a combination of these qualities to be recognized as recipients of divine grace (Digby, 2006: 711).

Historically, in line with the approach of the Deobandi reformist movement to Sufism, the leaders of the Tabligh Jama'ah have always been associated with the Divine attributes considered Bashar, or the assessment of ritual practices following Islamic jurisdiction. The supernatural power of a sheik can serve as an intermediary between man and God. His emphasis remains on the literacy skills mastered by the sheiks. The existence of the Jama'ah Tabligh, especially Maulana Muhammad Ilyas, harmonizes much with the attributes 
demanded in the Sufi tradition (Brunvand, 1979).

Field findings and based on hagiographic literature on the elite leadership of the Tablighi Jama'ah have clearly described that his appointment was always connected to Maulana Muhammad Ilyas, his successor, and ended with the Companions of the Prophet. For example, according to Nadwi (Nadwi, 1983: 125-127), the elite leadership of the Jama'ah Tabgligh is always associated with the quality and Sufistic attributes possessed by Maulana Muhammad Ilyas in his life and mission. The Tablighis always say that the qualities and characteristics possessed by Maulana Muhammad Ilyas are similar to the companions of the Prophet (Rah, 1999).

In Bijnauri's view, although the emirs of the Tablighi Jama'ah were not known for their juridical talent, they were very well trained in the Deobandi tradition. As mentioned above, Maulana Muhammad Ilyas had received direct guidance from Rashid Ahmad Gangohi, one of the most famous Deobandi scholars of his time. Hagiographers also state that his successors, Maulana Muhammad Yusuf Al-Kandahlawi and Inamu'l-Hasan, have a natural talent and interest in their religious education. For example, Bijnauri wrote that Maulana Muhammad Yusuf Al-Kandahlawi began memorizing the Qur'an when he was seven years old. He added that Maulana Muhammad Yusuf Al-Kandahlawi from the beginning had a great interest in reading and learning. Yusuf always set aside time to learn and reflect on each learning process to consider the blessing values. Well, Yusuf and Inamu'l-Hasan studied with Maulana Muhammad Ilyas until they started formal training at Mazahirul-'Ulūm Saharanpur. In hagiographic literature, they are described as close friends while in Mazahirul-'Ulūm and have been informed of getting the highest award each year (Bijnauri, 2001: 54).

Referring to the Book "Muntakhab-e Hadis" (Al-Kandahlawi, 2006), it shows his knowledge of the hadist, an essential component of education traversed in the Deobandi tradition. This text is divided into six parts and organized according to the traditions of the Tablighi Jama'ah. These texts have become the main reference in maintaining the Tablighi Jama'ah movement's durability by referring to the hadiths. The arguments contained in the work of Maulana Muhammad Yusuf Al-Kandahlawi clearly describe the basic principles of the organization of the Tablighi Jama'ah. This shows the authority of religious knowledge in its capacity as the elite leader of the Tablighi Jama'ah.

This elite leadership competence of Tablighi Jama'ah agrees with Digby's statement in his article that in the tradition of Sufi leadership, a sheik always develops an aura of exclusivity in their lives. They often have a reputation for enjoying temporary loneliness, but on the other hand, they show great concern for those who want their involvement in the inner circle of Shaykhs. In this context, efforts to balance personal reflection and social sensitivity enable a leader to maintain his charismatic personality. Maulana Muhammad Ilyas and his 
successors demonstrate the charismatic competence of his leadership in the Tablighi Jama'ah, who has the habit of seeking temporary silence regularly but remains sensitive to the well-being of the people around him. They have been accustomed to learning independently since childhood, devotion to totality, and often taking time alone in seclusion for a while (Bijnauri, 2001: 22).

The role of Sufism in the tradition of the Tablighi Jama'ah, especially as it relates to the concern for the belief in mystical authority in the organization, is part of the historical journey of the elite leadership of the Tablighi Jama'at movement. Reezt argues that informal criteria of leadership based on Sufistic traditions, such as personality, the charismatic, and moral authority, have become a consistent part of the ideology of the Tablighi Jama'ah. Building this authority, based on what Reetz (2006) refers to, is an "informal" criterion found in the discussion of the elite leadership of the Tablighi Jama'ah. The attention of the formal aspects of leadership based on the Sufistic tradition in the Tablighi Jama'ah also appears in specific displays, such as creating personal attachments to followers with elite leaders through mystical initiation. The formal aspect is an essential discourse in the tradition of the Tablighi Jama'ah because this aspect has expanded Maulana Muhammad Ilyas Ilyas's influence over the years since the beginning of his movement. Likewise, Maulana Muhammad Ilyas has strengthened his relationship with Mewat's people, especially to create the strength or legitimacy that underlies his movement. Despite the shift in the leadership style of the Tablighi Jama'ah conducted by Maulana Muhammad Ilyas refers to his personal ability to carry out collective actions. But mystical authority remains in its position as an essential aspect in building the legitimacy of elite leaders in the Tablighi Jama'ah.

Elite Leadership Jama'ah Tabligh Approaches to the Jurisprudence Tradition. Furthermore, the discussion about the authority of elite leadership jurisprudence in the Tablighi Jama'ah is also interesting to describe. However, Metcalf (2002: 8) asserts that the Taligh Jama'ah movement has characteristics as an organization that always avoids debates (khilafiah) with other Muslims about the goodness of jurisprudence and its details relating to ritual chapters. However, jurisprudential authority's formation has become an essential aspect in establishing legitimacy in the leadership aspect of the elite Tablighi Jama'ah movement. As explained earlier, this aspect of jurisprudence is related to the importance of the elite leadership of the Tablighi Jama'ah to build their competence in Islamic doctrine.

Referring to the learning of Darul-Uloom Deoband and Mazahirul-Ulum Saharanpur shows that the elite leadership tradition of the Tablighi Jama'ah also rests on the model of the legitimacy of religious authority through the reference it has mastered in their scientific achievements. This section shows the usage of the Tablighi Jama'ah commentary on the Qur'an and hadists. Both of these 
books become the media in establishing the jurisprudential authority of other scholars and ordinary Muslims. The construction of this authority agreed with Muhammad Qasim Zaman in connection with his study of contemporary Ulama. He said, scholars now have adapted to modernity, both in higher education, the use of print technology, the development of state bureaucracy, the influence of global capitalism, and others. This has all led the scholars to be flexible in their adaptation to the contemporary world (Zaman, 2007: 55).

Nephew of Maulana Muhammad Ilyas, including the elite member of Tabligh Jama'ah, namely Muhammad Zakariyya (d. 1982), was a prominent representative of the ownership of jurisprudential authority in the Tablighi Jama'ah organization. Zakariyya is a prolific writer, and his works are widely used as a reference by elite Muslim scholars and lay Muslims. His unique thoughts, including his Arabic commentaries on the Qur'an, hadists, and other works, have been designed to be used in the educational curriculum of madrassas built by the Tablighi Jama'ah.

Regarding Zakariyya's jurisprudential leadership recognition, in the tradition of the Tablighi Jama'ah adherence, their preachers are always advised to bring copies of their works while they are on tour (Khuruj fi sabilillah), especially his work on Fazā'ili-e A'māl. This work implicitly shows and explicitly maintains the religious authority of the ulama among the Tablighi Jama'ah. In this work, Zakariyya begins each essay in the chapters of the virtues of charity with certain verses from the Qur'an that show consideration of the proposition of qath'i from the nature of Islamic charitable practices. He then reproduces relevant hadiths to support his argument. Some essays also include stories from the lives of friends based on their own experiences that have provided many practical benefits.

Zakariyya inserts his comments throughout the text in his works. He often starts and ends each essay with his own words of advice-every verse of AlQur'an Hadith accompanied by translation, interpretation, and explanation. For the Tablighis, this is material or guidance to have pious behavior that has been presented through leadership in Zakariyya's essays. The dependence of the Tablighis on these essays has built Zakariyya's religious authority even stronger. In Fazā̄ilile A'māl, Zakariyya has also explicitly defended other ulama's power to assist in guiding the Muslim community. In his essay on Tabligh, Zakariyya has included a section on "Respect for Learning and Learning in Islam. This discussion serves as a reminder that lay members of the Tablighi Jama'ah organization do not know much of fundamental Islamic knowledge to participate in the delivery of Islamic symbols but may not enter into legal authority territory talks (Zakariyya, 2007).

Apart from the above reasons, the jurisprudential leadership authority in the Tablighi Jama'ah movement is an ability related to the intellectual capacity 
needed to understand very complex problems.

Zakariyya has confirmed the existence of the elite leadership authority of the Tablighi Jama'ah based on the approach of the jurisprudence tradition. Especially those relating to literacy competencies that are widespread in the Tablighi Jama'at literature. Lay members of the Tablighi Jama'ah organization are always encouraged to respect and study it. The elite leadership authority of the Tablighi Jama'ah relating to his works is ever constructed, discussed, made a reference, and maintained continuously. In that case, it was implicitly identified by the Tablighi Jama'ah as people who deserve to be respected and obeyed. The elite leadership of the Tablighi Jama'ah has established and maintained jurisprudential authority in the presence of its followers and members..

The lay leadership of Tablighi Jama'ah is an innovation in proselytism, which was institutionalized by Tablighi Jama'ah (Metclaf, 2002). Tablighi holds that the diffusion of lay leadership is firmly not a substitute for elite authority. According to a member of the Tablighi Jamaah, Lay leaders are not advised to take too much power because factually, they lack formal religious education.

Tablighi also believes that, however much the Tablighi Jama'ah encourages from all levels and educational backgrounds to participate in the suffering, they are not given the authority to take too much power. The structure of the body among lay leaders is limited to specific strengths and is not the same as the authority, which is the authority of elite leaders. Implementation of lay leadership authority is more often displayed on each tour with the appointment of an emir. During the visit, the leaders usually agreed to come from lay members of the community, who functioned to supervise participants during their missions. According to their experience in the organization, leaders are chosen according to their knowledge of da'wah programs, and their leadership qualities are not very clear. Amir tour has the responsibility of overseeing the logistics aspects of the trip. Resting, eating, sleeping, consulting local leaders, and inviting others to worship at the discretion of Amir, and tour participants are advised to obey them fully.

In Tablighi's view, the lay leadership of the Tablighi Jama'ah was only given significant authority in operational activities in the tour guide movement. Lay leaders of the Tablighi Jama'ah are given restrictions in exercising their power. Differences in excessive influence between members of the organization are not permitted, and this is the main principle in lay leadership rules. As part of the implementation of the fourth principle of Tablighi Jama'ah, i.e., MuslimIkram-e (respect for Muslims), leaders are instructed to avoid barriers to interaction by displaying seniority performances and juniority between them. Furthermore, while on tour, the emirs were encouraged not to show authority explicitly in their relations with fellow Tablighi's and fellow Muslims. In practice during tour tours, all participants, including lay emirs, are encouraged to eat together and mingle with all Tablighi in sharing the burden of menial tasks, not 
restricted by educational excellence and economic status (Talib, 1997).

According to Tablighi, lay Amirs were also instructed to decide certain matters with other group members before making decisions that would affect their sufferings. There is a visible deliberation process (consultation) that allows all Tablighi Jama'ah to voice their opinions on a particular issue. The discussion starts with reading the rules of the meeting. The rules dictate that each group member must give an open and honest opinion about the compilation of problems at the emir's request. Amirs should not expect or beg for their advice to be accepted. If the suggestion is approved, the emirs must be accustomed to asking for forgiveness from Allah and asking for protection from Allah for the accountability of the advice or advice they have received. If his help or information is not accepted, he must thank God because no burden will be collected from his participation in the deliberations. Everyone needs to advise on a problem even though the final decision is in Amir's hands. However, when announcing the decision, it should not make any show of authority or belittle others' opinions. Amir must thank other group members for their participation.

Group leaders must also support to allow their members to take on specific roles and tasks during the tour, even though they are newcomers to the Tablighi Jama'ah organization. For example, each group must have mutakallim (spokespersons) and rahbar (guides). Thus the picture, local missionary group organizations must always encourage the active participation of new members. The distribution of responsibilities is shared by groups and leadership structures fairly among Tablighi members to create "checks and balances" in the lay authority space (Masud, 2000: 28).

The meeting point, elite leadership with the laity in the Tablighi Jama'ah, lies in the authority of the Text in Context. Elite leadership as a writer and interpreter and the realm of lay leadership, reconfirm the writing and interpretation results. In this context, the elite and lay authorities intersect through the circulation of official Tablighi Jama'at literature. The author's authority is reconfirmed through text and context circulation. It is then reread to strengthen the leadership capacity of lay members by encouraging them to issue comments and elaborations. Thus, the text's authority in context is an essential path in the vertical relationship between the elite and lay leadership. The construction of elite jurisdiction in the document will always experience the repetition of exploration. Furthermore, the elite authority will experience articulation through text circulation in the creation of lay leadership authority through their verbal messages in the ritual cycle of tour guides (Masud, 2000: 29).

The texts also announce the religious contributions of their readers. In particular, members of the Tablighi Jama'ah who are recognized as having the authority of the book by their colleagues are those who are very experienced and 
have a significant contribution in distributing the literature of the Tablighi Jama'ah organization. Metcalf argues that elite leadership ideas that have been printed are never intended to stand alone, but rather to be read, discussed and presented in limited groups created by the Tablighi Jama'a preachers (Metclaf, 2002). Talib confirmed Metcalf's argument in his ethnography when he explained how local leaders were invited to lead discussions on the principles of the Tablighi Jama'ah. Lay leaders are given the honor to present and discuss the six main principles of the Tablighi Jama'ah (Talib, 1997).

One informant said that lay leaders were allowed to beautify the descriptions of the six principles with the allegory, metaphor, and story that developed in the community's traditions. If not deviate and can be accepted according to his experience in the Tablighi Jama'ah organization. The first speech type in building elite leadership authority. As for the comments, this is the primary genre to build elite leadership authority. Likewise, it is the same for building lay leadership authority. The public arrangement of recital texts (permissibility or ability to show) in oral form is a phase to increase the credibility of lay leaders in their local communities.

Strength of Individual Trust and Authority Training in the Tablighi Jamaat Dawat Program. Maulana Muhammad Yusuf Al Kandhawi told his followers in Mewati that he had affirmed your life and wealth in the Dawat program. Give your love to the Dawat program. Many of you come to visit and want to join me. But after that, you go back. Understand by you how much value in front of Allah is the program, so if you want to love and respect me, love, and respect this program in your hearts. Because I am a human being and when I will leave you. So what doesn't go away is the pre-work (Bijnauri, 2001). He confirmed the statement of Maulana Muhammad Yusuf al-Khandawi as the amir of the Tablighi Jama'ah as being impermanent. Because he ordered his followers to put their trust in the Dawat program, in this case, he has been seen as far more potent than any individual, even himself. As noted by Talib, the strength of this sense of trust was also recognized by the Dawat program (Talib, 1997). This view is a direct affirmation that the power inherent in the Dawat program will have consequences for the trust in the authority of individuals through their participation.

The Dawat program has become a source of strength for the Tablighis compared to the power of leadership. According to one of Tablighi that the Dawat program can deliver participants based on a deeply personal relationship between one's beliefs and God. In the Dawat program, the relationship between the believer and God begins with a sincere recitation of the Kalima. In the Dawat program, the Tablighis are guided by the power of a correct understanding of Kalima. They are means that people need to believe by putting their lives under the influence of their words. He must learn to reject the space of his heart for things contrary to kalmia (Bijnauri, 2001). Thus a meaningful 
relationship with God begins with his trust in the Dawat program.

Muhammad Zakariyya explained the above relationship through a mystical metaphor like a lover who symbolizes the subject of offering and being loved, or God. Zakariyya wrote it in the case of "worldly" love. According to him, a glimpse of a loved one has a magnetic effect, resulting in a lover's desire to see more. But according to him, "love can increase, and the longing of the heart may be satisfied, but the level of satisfaction can never actually be achieved. If worldly love produces such an intense longing for the lover, then the magnetic effect of God's glory is truly extraordinary. Zakariya wrote, "Allah Almighty, the Pure and Purified is the source of all beauty of every beauty. There is no beauty in this world except for Allah, a lover whose beauty and perfection knows no limits and unlimited (Zakkariya, 2007).

God, in turn, bestows kindness upon beloved servants. Zakariyya quoted Persia and Urdu Poetry to prove his point, namely: "The creator of humankind with its life has an incomprehensible and unimaginable relationship. He has a friendly relationship with all; He reaches the hearts of all people (Zakkariya, 2007: 17). This relationship with God provides comfort and peace of mind for people who believe. In Tablighi Jama'ah, this kind of relationship can only be found in the Dawat program's strength. In the Virtue of Prayer, Zakariyya explains how the Companions of the Prophet turned to prayer to regain peace of mind after suffering through personal tragedies such as the death of one of his loved ones (Zakkariya, 2007: 11). Likewise, in the virtue of zikr, Zakariyya writes that believers are organized to engage in remembrance to be able to enjoy happiness and peace of mind. Those who practice zikr because obedience to Allah will be encouraged to do so immediately to continue because they are very aware of the benefits it brings. Zikr is an excellent wealth for someone to give strength in dealing with various problems in his life. Following the Dawat program will thus influence one's belief in a relationship with God that will bring comfort and satisfaction to oneself.

Zakariya's quote reveals, believers are expected to build strong relationships with God naturally, and in doing so, someone will automatically become a better Muslim. Once a person believes and sincerely recites the kalima, one will feel compelled to seek divine love. Maintaining a relationship with God through prayer, remembrance, and dedication to suffering is finally easy for someone.

Furthermore, the power of trust is more dominant by proving the idea of loyalty following the exoteric guidelines of the Dawat program. This loyalty will naturally encourage believers to become better Muslims by absorbing the texts used as references. In this regard, Maulana Muhammad Ilyas has emphasized this point when explaining the right attitude towards work.

The Dawat Jama'ah Tabligh Program is a source of strength. According to 
the Tablighi Jama'ah figures, they can give participants access to religious truth. Tazkira Maulana Muhammad Yusuf al-Kandahlawi has recommended to his followers, "When listening to the Qur'an, consider that it is talking to God, and when reading or listening to a hadith, think that it is talking to the Prophet." (Bijnauri, 2001) He implies that believers can communicate directly with God; his words are empowering followers and giving unique feelings to understand God. The essential thing in this context is the strength of personal relationships between believers and God. Muhammad Ilyas.

The strength of individual believers is not too significant to the overall authority structure in the Tablighi Jama'ah. However, the most ideal authority in the Tablighi Jama'ah is the faithful who always follow the Dawat program. Through the Dawat program, the Tablighis can recognize who can be relied on, trusted, and have the power to guide in religious matters. His personal relationship with God and his religious experience will guide him to true leaders. Lay believers from the Tablighi Jama'ah thus supporting their elite leaders are not subjective but very objective based on their meeting and religious experience together in exercising authority through the Dawat program.

Thus, the exercise of the ideal authority in Jamā'at Tabligh is illustrated through the effective Dawat training program to invite others. So they can reform their spiritual life. However, the method of delegating authority in the Tablighi Jama'ah is complicated. Therefore, the organizational structure of the Tablighi Jama'ah organization depends on the balance of elite leadership, which refers to mystical, jurisprudential authority, and the existence of lay leadership. The complexity comes because individually lay leaders are given authority in matters of religion. It depends on the power of influence that comes from various sources; mystical charisma, jurisprudence education, organizational experience, and religious practice. All are obtained by believers when exercising authority in the Dawat program.

\section{The Construction Identity of Da'wah Leadership in The Jama'ah Tabligh}

Weber discusses charisma as a starting point for developing charismatic leadership models and authority. Although previously, contemporary thinkers separate and distinguish between the understanding of religious appeal and political charm. Separation is based on an empirical understanding of the charismatic leadership of the twentieth century, such as the presence of Hitler and Mao Tse Tung. The charisma of religious contexts with political nuances, such as in the 1978 Jonestown assassination and suicide and the 1999 subway gas attack Awn Shinrikyo (Bromley \& Melt).

The elite leadership of the Tablighi Jama'ah, as described earlier, seemed to have been inspired by the power of charismatic authority in the early stages of its construction. Like, the members' respectful attitude towards individuals who are considered to have spiritual experiences in Mewat. Maulana Muhammad 
Ilyas, Maulana Muhammad Yusuf al Kandahlawi, and others have the power of charisma in the eyes of the Tablighis. They are very loyal because they are considered charismatic leaders. The charismatic power of the Tablighi Jama'ah leader is sometimes associated with mysticism because of his spiritual experience. This changes the religious tradition of giving birth to the obedience of its members. Adherence to ethical practices is based on leaders, for example, fully involved in solemnly in khuruj fi sabilillah.

Weber (1947, in Turner, 1990: 38) states that charismatic authority has led one group to be more inclined to follow its leader in-depth and provide secure experience in some issues. In the context of the elite leadership of the Tablighi Jama'ah, the authority of this charisma refers to the attribution of extraordinary individuals, supermen, or possessing supernatural powers. They are seen as authorized to lead, change, and renew religious traditions that have developed and come out of the principles of the purity of spiritual teachings.

From the perspective of management theory, the process of exercising charisma authority in the Jama'ah Tabligh program, charismatic authority is a process of identifying each other in various ways in which followers can relate to leaders, detailing psychological and personal factors that influence charismatic connections. In the exercise of charismatic authority and jurisprudence in the Dawat program, the distribution of roles and functions of leadership in the Tablighi Jamaah has been an essential factor in the birth of charismatic authority. Charismatic authority born of collective spiritual practice, which is shown in roles responsibly and simultaneously (Howell \& Shamir, 2005: 96).

According to Willner, charismatic leadership's main requirement is the leader's self-identity that resonates with the early followers, following the existing cultural text. Willner shows the way leaders display and design behavior to utilize mystical expectations in their culture so that charismatic legitimacy (Willner) is created. The tradition of the Tablighi Jama'ah, leaders, generally identify themselves when called upon in the sacred mission of Dawat. This summons often follows periods of personal search and effort to form charismatic identities. Charismatic identity converges from time to time when a leader gains followers and confidence. At this stage, the initial formation of the charismatic character of the leaders of the Tablighi Jama'ah (Wallis, 1982: 25).

The maintenance of charismatic authority as a strategy of the legitimacy of leaders in the Tablighi Jama'ah environment based on empirical analysis consists of pure charisma, traditional (based on respect for the past), and rational-law (based on mutual acceptance of a set of normative rules). However, researchers see that in the Tablighi Jama'ah, the three types are often mixed and cannot be separated from one another. In analyzing the stratification of the legitimacy of the Tablighi Jama'ah leader, the researcher has agreed on the views of Weber, Lewis, and Barker about charismatic authority (Weber, 1987). 
It seems that the charismatic leaders of the Tablighi Jama'ah always strengthen their legitimacy by using a strategy of appealing to institutional and traditional authorities. The first strategy is to show the charisma of leadership in the Tablighi Jama'ah directly through superior power and wisdom through insight, the creation of scripture, and a description of the vision. It can be seen from the works, Maulana Muhammad Ilyas and Maulana Yusuf Alkandahlawi. The second strategic finding is strengthening the legitimacy of charismatic authority through the appeal of rationality.

Based on observations, there are four ways Tablighi maintains charismatic leadership: (1) Elite followers help followers in developing and preserving charisma; (2) Ordinary followers come to accept the appeal of the leader through the process of charismatization; (3) Followers bring their history into groups, which reflects their nature. (4) Individual perceptions of followers gained during their involvement in tour visits change bonds over time (Barker, 1993: 97). As seen in the Tablighi Jama'ah, the first level of followers becomes "charismatic aristocracy," which has the role of protecting the charisma of elite leaders. Lay leaders try to protect the position of elite leaders and avoid competition with the external. Followers introduce leadership charisma in the momentum of new recruitment in the Dawat program. His followers develop charismatic impressions of leaders in the form of messages that are lethargic.

Followers of Tablighi Jama'ah play a role in charismatization. The identification process called Barker a learning tool in bringing followers to understand and appreciate the charisma of leaders. Respect for charismatic authority is the learned behavior of followers of the Tablighi Jama'ah towards its leader. The process is carried out in the Dawat cycle. The view of the Tablighi Jama'ah leader was transformed through charismatization and personal experience so that the Tablighi can recognize individuals in placing different interpretations on the charismatic ties of their leaders.

Furthermore, the acquisition of charismatic authority in the leadership of the Tablighi Jama'ah has a strong relationship with the personality and experience of the followers. In the Tablighi Jama'ah, the power of the elite's charismatic leadership is shown in each of his followers' visits to the center of the Tablighi Jama'ah movement in New Delhi, Maskas Nizamuddin. In this case, the connection between emotions and spiritual experiences is evident. In this case, I agree with Barker and Lewis. They have been of the view that, at one time or another, they experience an emotional relationship with the group leader, even though they are not interested in joining the group (Barker, 1993).

Apart from contrary opinions, elite leaders of the Jamaah Tabligh realized the need for routine. Routines can formalize the process of creating authority in a leadership career, systematize work, and transfer charisma into the scriptures or procedures related to the course of the group's movement (Bromley, 2014: 103). 
Referring to the opinion of Peter L. Berger (1991: 32), the construction of religious identity in the leadership dimension of the Tablighi Jama'ah is the result of simultaneous dialectics, namely the three moments of externalization, objectivation and internalization between leaders, followers (Tablighi) and the environment. In training the leadership authority of the Tablighi Jama'ah, this process, namely: 1) The externalization stage has shown the process of adaptation of the leadership roles of the Tablighi Jama'ah, both at the elite, jurisprudential and lay levels with the socio-cultural world that is in the location or destination of the Dawat (khuruj fi sabilillah); 2) The objectivation stage has demonstrated the interaction of leadership roles in the Tablighi Jama'ah with the intersubjective world institutionalized or subjected to institutionalization (Dawat or kuhuruj fi sabilillah), and; The internalization stage has shown its members (Tablighi) or non-members (non-Tablighi) to identify leadership roles, whether elite, jurisprudential or lay in programs that have been established by the Tablighi Jama'ah as religious institutions or organizations where individuals become members or as members partisan only.

\section{CLOSING}

The concept of leadership of the Tablighi Jamaah is called "charismatization". The emergence of the charismatic expression of the preaching of the Tablighi Jama'ah was examined based on spiritual experience and internal processes. It shows that the follower accepts his charismatic authority through "charismatization." The field leadership findings of the Tablighi Jama'ah through training of the Dawat program authority strengthen charismatic leadership through the transformational leadership performance model. Training the leadership authority of the Jama'ah Tabligh ritual program finds the vision and mission transformation through the idealized influence of the leader. Inspirational motivation from the leader to the members This is intellectual stimulation. The existence of individualized consideration is shown through the leader's behavior by giving personal attention to followers.

The construction of the Da'wah Tablighi preaching leadership identity is a combination of charismatic and transformational authority. Charisma authority refers to the attribution of the individual leaders of the Tablighi Jama'ah, who are considered extraordinary, superhuman, or have supernatural powers. They are seen as having the authority to lead, change, and renew religious traditions that have developed in society. A deviant religion is returned to its value and function by the Tabligh worshipers.

\section{REFERENCES}

Al-Kandahlawi, M.M.Y. (2006) Muntakhab Ahadits, terj. Ahmad Nurkbolis al Adib, Yogyakarta: Ass-Shaff. 
Arifin, Z. (2017). The Authority of Spiritual Leadership at Pesantren Temboro Based on Jamaah Tabligh Ideology'. Jurnal Pendidikan Islam, 6(2), 265-292. DOI : 10.14421/jpi.2017.62.265-292

Barker, E. (1993) Charismatization: The Social Production of 'an Ethos Propitious to the Mobilisation of Sentiments: In Eileen Barker, James Beckford, and Karel Dobbelaere, eds. Secularization, Rationalism and Sectarianism: Essays in Honour of Bryan R Wilson, Oxford: Clarendon Press.

Berger, P.L. \& Luckman, T. (1991) Tafsir Sosial atas Kenyataan: Risalah tentang Sosiologi Pengetahuan, Jakarta: LP3ES.

Bijnauri, A.R. (2001). Tazkira-ye Amìr-e Tablïgh, Karachi: Zam Zam Publishers.

Bromley, D. \& J. Melton, J. G. (ed.) (2002) Cults, Religion and Violence. Cambridge: Cambridge University Press.

Bromley, D.G. (2014) Charisma and Leadership: Charisma and Charismatic Authority in New Religious Movements (NRMs), In George D. Chryssides and Benjamin E. Zeller, eds. The Bloomsbury Companion to New Religious Movements, New York: Bloomsbury Academic.

Brunvand, J.H. (1979), Readings in American Folklore, Amerika: W. W. Norton \& Company Published.

Digby, S. (2006) The Sufi Shaikh as a Source of Authority in Medieval India in India's Islamic Traditions, (ed. Richard Eaton), New York: Oxford University Press.

Hasanah, U. (2014). Keberadaan Kelompok Jamaah Tabligh dan Reaksi Masyarakat (Perspektif Teori Penyebaran Informasi dan Pengaruh). Jurnal Indo-Islamika, 4(1), 21-44. https://doi.org/ 10.1548/idi.v4i1.1559

Hasfi, N., Usman, S., \& Santosa, H. P. (2017). Representasi Kepemimpinan Calon Presiden Di Twitter. Jurnal Aspikom, 3(2), 270-284. bttps://doi.org/10.30739/darussalam.v9i2.229

Hasyim, N. M. (2018). Media Dan Konstruksi Identitas Kepemimpinan. Jurnal Darussalam: Jurnal Pendidikan, Komunikasi dan Pemikiran Hukum Islam, 9(2), 256-282. http://jurnalaspikom.org/index.php/aspikom/article/view/133/118.

Howell, JM.,\& Shamir, B. (2005) The Role of Followers in the Charismatic Leadership Process: Relationships and Their Consequences, dalam Journal ob The Academy of Management Review 30(1): 6- 112. doi/abs/10.5465/AMR.2005.15281435

Masud, M.K. (2000) Growth and Development of the Tablighi Jama'at. Travelers in Faith: Studies of the Tablighi Jama'at as a Transnational Islamic Movement for Faith Renewal, Leiden: Brill.

Metcalf, B. (2002) Traditionalist Islamic Activism: Deoband, Tablighis, and Talibs, dalam Understanding September, (ed. Craig Calhoun, Paul Price \& Ashley Timmer), New York: The New Press.

Mundiri, A., \& Bariroh, A. (2018). Transformasi Representasi Identitas Kepemimpinan Kyai dalam Hubungan Atasan dan Bawahan. Al-Idarah: 
Dudy Imanuddin Effendi \& Dudi Rustandi

Jurnal Kependidikan Islam,8(2), 234-255. https://doi.org/ 10.24042/alidarah.v8i2.2411

Munir, A. (2017). Akar Teologis Etos Kerja Jamaah Tabligh Studi Kasus Komunitas Jamaah Tabligh Desa Temboro Kecamatan Karas Magetan. Kodifikasia, 11(1), 50-71. 10.21154/kodifikasia.v11i1.1137

Mustain, M. (2018). Islamic Center dan Peran Kekuasaan dalam Konstruksi Identitas Islam di Lombok. Jurnal Penelitian LPPM LAIN Kudus, 12(2), 287316. http://dx.doi.org/10.21043/ jp.v12i2. 4075.

Nadwi, A.H.A. (1983). Life and Mission of Maulana Mobammad Ilyas. Lucknow: Academy of Islamic Research and Publications.

Nottingham, E.K. (1996). Agama dan Masyarakat: Suatu Pengantar Sosiologi Agama, Jakarta: Rajagrafindo Persada.

Rah, M.M.Z.K. (1999) Hayatus Sahabah, Yogyakarta: Ash-Shaff.

Reetz, D. (2006). Sufi Spirituality Fires Reformist Zeal: The Tablighi Jama'at in Today's India and Pakistan, dalam Journal of Archives de Sciences Sociales des Religions. 13 (5), 33-51. https://doi.org/10.4000/ assr.3715

Talib, M. (1997) The Tablighis in the Making of Muslim Identity, dalam Journal Comparative Studies of South Asia, Africa and the Middle East. 17 (1). bttps:// doi.org/10.1215/1089201X-17-1-32

Turner, B.S. (1990) Sosiologi Islam; Suatu Telaah Analistis Atas Tesa Sosiologi Weber, Jakarta: Rawajali Press.

Wallis, R. (1982) The Social Construction of Charisma, dalam Journal of Social Compass 29 (25): 25-38. https://journals.sagepub.com/ doi/ $10.1177 / 003776868202900102$

Weber, M. (1968) Charisma and Institution Building, Chicago: University of Chicago Press.

Weber, M. (1987) Economy and Society: An Outline of Interpretive Sociology, Los Angeles: University of California Press.

Willner, A.R. (1984) The Spellbinders: Charismatic Political Leadership, New Haven, CT: Yale University Press.

Zakkariya, M. (2007) The Virtues of the Holy Qur'an." Teachings of Islam, Des Plaines: Library of Islam Publishers.

Zaman, M.Q. (2007) The Ulama in Contemporary Islam: Custodians of Change, Princeton: Princeton University Press. 